\title{
PRAVA IZBJEGLICA I AZILANATA U ISLAMU
}

\section{Sažetak}

Cilj ove studije je da odgovori na pitanja da li azilanti i izjjeglice, po učenju islama, imaju svoja prava, koja su $i$ da li ib danas istinski uřivaju, a potom da napravi komparaciju izmedu njihovih prava $u$ islamskom alkonodavstvu $i$ medunarodnom pravu.

Očito je da su danas najbrojnije irbjeglice muslimani, da se njibov broj, iz dana $u$ dan, u svijetu pové́ava $i$ da se većinom nalaze u lošem položaju. Cinjenica je da vecina izjjeglica u mnogim zemljama ne uřvivaju svoja prava $i$ to najčš́ce zato što se dræ̌ave u kojima obitavaju oglušuju kada je riječ o postivanju njihovih obaveza koje imaju prema izbjeglicama, kao $i$ zbog nepoznavanja tih prava od strane samih irbjeglica i aquilanata. Medutim, ta prava su im zagarantovana i u islamskom ǘenju i u medunarodnim dokumentima o ljudskim pravima.

Da bi studija polučila očekivane requltate, bilo je neophodno istrą̧iti pojam iabjeglistva u Kur'anu i sunnetu, kao i u međunarodnom pravu, vrste iabjeglistva u klasicnom periodu, usroke izbjeglistva u islamskom $i$ medunarodnom pravu, prava izbjeglica i prestanak statusa izbjeglice u islamskom i medunarodnom pravu.

Ključne riječi: ažil, iæbjeglice, islam, Šerijat, izbjeglica, islamsko pravo, medunarodno pravo, prava, obaveze

\section{Uvodni dio}

Allah je na mnogim mjestima u Kur'anu rekao da je odabrao i odlikovao čovjeka nad ostalim stvorenjima. To je i osnovni princip islamske doktrine, koji je općeprihvaćen od strane muslimana i dosljedno primjenjivan od samog spuštanja čovjeka na Zemlju, pa sve do danas, bez ikakve rasne ili bilo koje druge diskriminacije. Dakle, islam je odmah na početku ljudske prapovijesti priznao čovjeku njegova prava zbog njegove odlikovanosti i cilja, radi kojega je i stvoren.

Međutim, kao posljedica savremene civilizacije koja je zanemarila spomenuto božansko načelo i uspostavila svoje temelje na sukobima i konfliktima, neminovno se javio i problem izbjeglica $i$ azilanata koji,

\footnotetext{
${ }^{1}$ Islamski pedagoški fakultet u Bihaću
} 
bježeći od konfliktnih i ratnih žarišta, traže sigurna mjesta za sebe i svoje porodice.

Problem izbjeglica i azilanata je bez sumnje jedan od najtežih i najzamršenijih problema savremene civilizacije. Ova ljudska populacija je danas najnezaštićenija i stoga je najviše izložena nepravdi i raznim vrstama tortura. To je posebno izraženo u posljednjih nekoliko desetljeća prošlog, kao i početkom ovog vijeka, kada se javljaju bezdušnici koji, bez imalo srama i stida, počinju trgovati sa ljudskim svetim pravima, nudeći protunaknadu za njih - materijalna sredstva, naizgled lagodne živote i državljanstvo zemalja u kojima borave.

Navedeni i njima slični problemi, s kojima se susreće ova populacija, potvrđuju značaj i važnost ove teme, te elaboriranja iste, kako sa strane islamskog, tako i sa strane međunarodnog prava. Ova studija namjerava se osvrnuti na samo mali dio njihovih problema i elaborirati i pojasniti teorijska prava izbjeglica u islamu, njihovu važnost, te odgovoriti na pitanja da li je islam po pitanju tih prava bio preteča u odnosu na ostale ideologije i pravne sisteme ili nije. Također, namjera je i da se utvrdi koliko se ta prava uistinu poštuju i primjenjuju u praksi, tj. u zemljama u kojima žive azilanti i izbjeglice sukladno deklaracijama i dokumentima u kojima se ona deklarativno priznaju u islamskom, ali i u međunarodnom pravu. I na kraju, studija će se osvrnuti i na stav islamskog i međunarodnog prava po pitanju anuliranja i kompenzacije ovog prava.

Važnost ove studije se ogleda i u tome što će ona, nadamo se, biti jedan skromni pokušaj odgovora na lažne tvrdnje, sumnjive sugestije i namjerne klevete upućene islamskom zakonodavstvu po pitanju prava azilanata i izbjeglica. Dakle, pokušat će, makar i simbolično, participirati u iznalaženju rješenja za ovo, mogli bismo reći, najteže pitanje današnjice. Također, smatramo da se, u odnosu na važnost i obim ovog problema, malo diskutovalo i pisalo o njegovom prevazilaženju i iskorjenjivanju, kako sa strane islamskog zakonodavstva, tako i sa strane međunarodnog prava. 


\section{Pojam i definicija termina azilant - izbjeglica}

\section{Semantičko značenje}

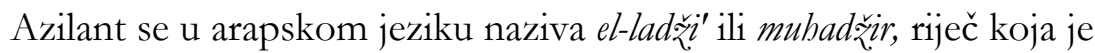

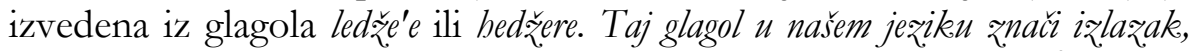
napustanje, osamljenje, prisiljavanje na nesto, trašenje zaštite od nekoga itd. ${ }^{2}$

\section{Azilant u međunarodnom pravu}

Definiranje azilanta u međunarodnom pravu je veoma bitno pitanje, pa čak i esencijalno pri rješavanju problema izbjeglica. Od te definicije zavisi i zakonska zaštita onih na koje se odnosi ta definicija. Isto tako, ovdje je bitno istaći da se definicija azilanta ili izbjeglice razlikuje od korisnika do korisnika, kao i od geografskih podneblja i ugovora.

Međunarodno pravo nije dalo samo jednu definiciju azilanta/izbjeglice. Navode se i koriste dvije najpoznatije definicije koje se upotrebljavaju u relevantnim izvorima i djelima međunarodnog prava.

Prema prvoj definiciji, arilant/izbjeglica je svaki conjek ciji su život, zdravlje ili sloboda iə̌lǒ̌eni opasnosti sukladno Univerzalnoj deklaraciji o ljudskim pravima. Takvima je, po medunarodnom pravu, dozvoljeno zatra žiti azil. ${ }^{3}$

Po drugoj definiciji, azilant/izbjeglica je svaki covjek koji je napustio svoju maticnu domovinu ili je protjeran iz nje sredstvima zastrašivanja pa je ₹bog toga doša na teritoriju druge drỹave tražéci zaštitu, ili to je osoba kojoj je zabranjeno da se vrati u maticnu zemlju. ${ }^{4}$

\section{Srodni izrazi}

Treba napomenuti da izraz ažilant nije jasno naveden i korišten u glavnom izvoru islamskog prava - Kur'anu, ali postoje slični i srodni izrazi koju određuju njegovo značenje poput izraza el-istiď̌are (traženje zašite), el-isti'man (traženje sigurnosti), el-bidæ̌ra (iseljenje) i ibnus-sebil

2 Ibn Menzur, Lisanul-'arab, (1152), Fejruz Abadi, El-Kamusul-mubit, 1/27., Muftić, Arapsko-bosanski rječnik, str. 1333-1334.

${ }^{3}$ Ebu Hejf, Ali Sadik, El-Kanunud-devlijul'am, str. 249.

${ }^{4}$ Ganim, Muhammed Hafiz, Mebadi'ul-kanunid-devlijjil-'am, str. 549. 
(putnik). Ukratko ćemo se osvrnuti na ove izraze i pojasniti njihova značenja.

El-istiď̃are je traženje sigurnosti i zaštite. U tom smislu Uzvišeni kaže: Ako te neki od mnogobožaca zamoli za zaštitu, ti ga zaštiti da bi saslušao Allahove rijeři, a potom ga otpremi na mjesto pouzdano za njega. To zato sto oni pripadaju narodu koji ne zna. (Et-Tevba, 6)

Arapi kažu: Edžareke Allahu minel-az̧ab. (Allah te zaštitio od vatre.)

El-Muste'min je onaj koji traži sigurnost i ugovor. To je onaj koji dođe u harem štiteći se na osnovu njegove svetosti. Islamsko pravo poznaje ovakvu vrstu zaštite ili imuniteta. Potvrđuju ga i Kur’an i sunnet.

Uzvišeni kaže:

„I učinili smo Hram utočistem i sigurnim mjestom ljudima. Neka vam mjesto na kojem je stajao Ibrabim bude prostor iza koga cete molitvu obavljati! - I Ibrabimu i Ismailu smo naredili: „Hram Moj očistite za one koji ga budu obilazili, koju budu tu boravili i koji budu molitvu obavljali. "(El-Bekare, 125)

Dakle, ko uđe u mekanski harem kao azilant - siguran je, a to potvrđuje hadis u kojem Poslanik, a.s., kaže: „Ko uđe u mekanski harem siguran je, ko ude u kucu Ebu Sufjana siguran je, ko baci oruřje siguran je $i$ ko zaključa svoja vrata siguran je." 5

Hidæ̌ra - u arapskom jeziku, u svom osnovnom značenju, jeste izlazak beduina iz pustinje u urbanu sredinu, ili izlazak iz jedne u drugu zemlju. Zbog maltretiranja i ponižavanja u prvo vrijeme islama, muslimani su bili prisiljeni učiniti preseljenje iz Mekke u Etiopiju, a nakon toga iz Mekke u Medinu. Opisujući te događaje, Uzvišeni je rekao: „I siromašnim mubadð̌irima koji su iz rodnog kraja svoga protjerani i imovine svoje lišeni, koji žele da Allahovu milost i naklonost steknu, i Allaha i Poslanika Njegova pomognu - to su, zaista, pravi vjernici. "(El-Hašr, 8)

Ibnus-sebil je putnik namjernik koji se, nakon obavljenog posla, řeli vratiti $u$ svoje mjesto boravka, ali nema sredstava za to. On ima pravo na zekat. Vecina islamskih pravnika smatra da je to svaki putnik koji je otputovao iz. svog mjesta $u$ drugo. ${ }^{6}$

\footnotetext{
${ }^{5}$ Bilježi ga Muslim, Knjiga o džihadu i vojnim pohodima, Poglavlje o osvojenju Mekke, hadis br. 1780 .

${ }^{6}$ Karadavi, Jusuf, Fikhur-zeka, 1/67.
} 


\section{Termin azil u Kur'anu i sunnetu}

\section{U Kur'anu}

Već je rečeno da termin azil nije eksplicitno upotrijebljen u Kur'anu, ali su navedeni drugi termini koji involviraju njegovo značenje. U nastavku ćemo selektivno navesti neke ajete koji sadržavaju spomenute termine.

Uzvišeni je rekao: „Ako te neki od mnogobožaca zamoli za zaštitu, ti ga zaštiti da bi sasluša Allabove riječí, a potom ga otpremi na mjesto pouzdano za njega. To zato što oni pripadaju narodu koji ne zna. "(Et-Tevbe, 6)

Dakle, u ajetu se Allah obraća Poslaniku govoreći mu: „Muhammede, ako te bilo koji idolopoklonik zamoli za zaštitu daj mu je i ne ubijaj ga. Omogući mu da saslusa Allabov govor kako bi razumio Njegove naredbe $i$ zabrane. Pa ako odbije primiti islam vrati ga na sigurno mjesto i stiti ga sve dok ne dode do svoje domovine."

Uzvišeni veli: "O vjernici, kada u boj krenete, na Allahovu putu, sve dobro ispitajte i onome ko vam nazove selam ne recite: "Ti nisi vjernik!" - kako biste se domogli ovozemaljskih dobara; ta u Allaha su mnoge dobiti! I vi ste prije bili kao oni, pa vam je Allah darovao milost Svoju; zato wijeke sve dobro ispitajte, a Allabu je, zaista, poznato ono sto radite." (En-Nisa, 94) U ajetu, Allah naređuje vjernicima da daju sigurnost i garanciju onima koji su se prestali boriti protiv njih.

Prenosi se da je Mirdas b. Nuhejk jedini primio islam iz svog naroda. Potom je Poslanik, a.s., poslao izvidnicu njegovom narodu pod vodstvom Galiba b. Fudale. Narod se sklonio, a Mirdas je ostao, vjerujući da će ga to što je primio islam zaštiti. Nakon što je ugledao konje, uputio se sa svojim stadom ka vrhu planine. Kada su ga stigli, donijeli su tekbir i on je donio tekbir, spustio se i rekao: „Nema boga osim Allaha", vjerujući u te riječi i tražeći zaštitu sa njima od njih. Međutim, Usame b. Zejd ga je ipak ubio i potjerao njegove ovce. Kada su o tome obavijestili Poslanika, a.s., to mu je vrlo teško palo pa ih je ukorio rekavši: „Zar ste ga ubili ₹̌ndeći za onim što je bilo s njim?!"

Potom je proučio citirani ajet. Usame je rekao: „Allahov Poslaniče, zatra ži oprosta za mene. "„Kako da to uradim, a izgovorio je šehadet", odgovorio mu je Poslanik, a.s. Usame je rekao: „Neprestano je to irgovarao i negirao tako da sam

\footnotetext{
${ }^{7}$ Kurtubi, Ebu Abdullah, El-D乏̌ami'u li abkamil-Kur'an, 8/76.
} 
požalio što sam prije toga primio islam. Nakon toga je zatražio oprosta za mene rekavši mi da oslobodim roba." ${ }^{8}$

\section{U sunnetu}

U mnogobrojnim hadisima se dozvoljava davanje azila onima koji se obrate Poslaniku, a.s., i njegovim ashabima, npr.:

- Od Ibrahima b. Tejmija od njegova oca se prenosi da je rekao: „Od Poslanika, a.s., nismo ništa pisali osim Kur'ana $i$ ovog što se nalari na ovoj ploči. Poslanik, a.s., je rekao: „Medina je zabranjena od Atira pa do toga i toga, pa ko uvede neku novotariju ili pribvati novotara neka je nad njim Allahovo prokletstvo, prokletstvo Njegovih meleka $i$ svih ljudi. Allah od njega neće primiti nikakvo dobro djelo. Garancija muslimana je jedna $i$ oni koji nisu muslimani žnde za njom. $\mathrm{Pa}$ ko od muslimana prekrši tu garanciju, nad njim je Allahovo prokletstvo, prokletstvo Njegovih meleka $i$ svih ljudi, i Allah od njega neće primiti nikakvo dobro djelo." $\mathrm{U}$ citiranom hadisu se jasno potvrđuje svetost Medine kao i zabrana uznemiravanja nemuslimana - građana islamske države. To je u stvari eman - zaštita.

Hafiz u tom smislu veli: „Garancija o zastiti muslimana je jedna, tj. ispravna pa ko god je od njih dadne nemuslimanu, ostalim muslimanima je zabranjeno zanemariti je. “10

- Od Ebi Nadra, štićenika Omera b. Ubejdullaha, se prenosi da ga je Ebu Murre, štićenik Ebu Talibove kćerke Umm Hane, obavijestio da je čuo Umm Hanu, Ebu Talibovu kćerku da je rekla: „Otišla sam Allahovom Poslaniku, s.a.v.s., na dan oslobođenja Mekeke pa sam ga zatekla kako se kupa, a njegova kírka Fatima ga zastire. Naqvala sam selam, a on je upitao: „Ko je to?" Rekla sam: Ja, Umm Hana, Ebu Talibova kíerka. „Dobro došla Umm Hana", rekao je. Kada se okupao, klanjao je osam rekjata ogrnut u jednoj odjećí. Rekla sam: Allahov Poslaniče, sin moje majke Alija turdi da će ubiti covjeka kome sam dala aril, a to je Fulan b. Hubejr. Allahov Poslanik, s.a.v.s., je rekao: „Mi pribvatamo azil od onog kome si ga ti dala. "11

\footnotetext{
8 Sujuti, Dželaluddin, Lubabun-nukul fi esbabin-nuzul, str. 104.

${ }_{9}$ Bilježi ga Buharija u svom Sahihu, Knjiga o hadždžu, Poglavlje o Medinskom haremu, hadis broj: 1771 .

10 Askalani, Ahmed b. Hadžer, Fethul-Bari Šerbu Sabibil-Bubari, 4/125.

11 Bilježi ga Buharija u svom Sahihu, Knjiga o namazu, Poglavlje o klanjanju ogrnut u jednoj odjeći, hadis broj: 350.
} 
U hadisu se jasno nalaře da je obaveza svih muslimana poštovati aril kojeg je dao neko od muslimana, pa makar se radilo i o muslimanki, pod uvjetom da ga odobre nadležne vlasti. ${ }^{12}$

\section{Razlozi azila $u$ islamskom i međunarodnom pravu}

Kroz cijelu historiju ljudskog roda azilanti su bili ljudi koji su tražili pomoć, zaštitu i skrb, posebno u teškim uslovima koji su se razlikovali od vremena do vremena. Svi njihovi zahtjevi su bili zapravo prava koja su im islamsko pravo i međunarodne deklaracije priznali. U nastavku studije slijedi osvrt na razloge traženja azila $u$ islamskom i međunarodnom pravu, a potom ćemo izložiti vrste azila.

\section{Razlozi traženja azila u islamskom pravu}

$\mathrm{U}$ islamskom pravu azil se traži zbog slijedećih razloga:

\section{Izlazak iz islamske države u neislamsku}

Kome se u nekoj zemlji ne dozvoljava upražnjavanje vjerskih osjećaja i obaveza, tj. kome su ugrožena osnovna ljudska prava, obavezan je učiniti hidžru iz takve zemlje. O tome Kur'an jasno govori u mnogobrojnim ajetima:

Onaj ko se iseli Allaha radi naci će na Zemlji mnogo mjesta, usprkos svojih neprijatelja, $i$ slobodu. A onome ko napusti svoj rodni kraj radi Allaba i Poslanika Njegova, pa ga stigne smrt, nagrada od Allaha njemu je sigurna. - A Allab mnogo prašta i milostiv je. (En-Nisa, 100)

Hidžra je bila vadžib za vrijeme Poslanika, s.a.v.s., i do Sudnjeg dana zadržala je takav status u svakom vremenu i prostoru kada god se ispune za nju određeni uslovi.

\section{Napuštanje mjesta u kojem je prevladala smutnja, nemir i novotarija}

$\mathrm{Na}$ to stanje Kur'an jasno ukazuje u slijedećem ajetu: Kada vidiš one koji se riječma Našim rugaju, nek si daleko od njï sve dok na drugi razgovor ne

12 Askalani, Fetbul-Bari Šerbu Sabibil-Bubari, 1/70. 
predu. A ako te šejtan navede da zaboraviš, onda ne sjedi više s nevjernicima kad se opomene sjetis. (El-En'am, 68)

Ajet eksplicitno zabranjuje miješanje sa nasilnicima koji inoviraju u vjeri, koji stvaraju nesigurnost i remete red na Zemlji pa Kur'an naređuje distanciranje od njih.

\section{Strah za svoju čast i imetak}

Svetost tih stvari u islamu je neprikosnovena i ima status svetosti života.

\section{Napuštanje mjesta zbog bojazni za svoj život i tijelo}

To je milost koju je Bog podario čovjeku. Dakle, ako se neko bude bojao za svoj život, Allah mu je dozvolio da napusti to mjesto i ode u mjesto gdje će se sigurno osjećati. Prvi koji je iskoristio to pravo bio je Ibrahim, a.s. Govoreći o njegovu životu, u Kur'anu se kaže da je on izrekao i ovo:

„Idem onamo gdje mi je Gospodar moj naredio“, reče, „On će me kuda treba uputiti." (Es-Saffat, 99)

\section{Izbjegavanje mjesta u kojem se pojavila neka opasna zarazna bolest poput kuge}

Poslanik, a.s., je zabranio da se ide u takevu zemlju, kao i da se izlazi iz nje nakon što se pojavi takva bolest. ${ }^{13}$

\section{Razlozi traženja azila u međunarodnom pravu}

$\mathrm{U}$ međunarodnim dokumentima koji govore o azilantima navode se slijedeći razlozi za opravdano traženje azila:

1. strah koji je posljedica bojazni od kažnjavanja i ugnjetavanja. To je posebno duševno stanje koje nalaže azilantu da potraži mjesto gdje će osjećati sigurnost i mir,

2. ugnjetavanje koje je posljedica provokacija i prijetnji životu, slobodi i narušavanje ljudskih prava koja su priznata putem međunarodnih deklaracija i povelja,

${ }^{13}$ El-Ebtah, Se'id, El-Ladřiune fil-mefhumil-islami, str. 29. 
3. segregacija - razdvajanje ljudi na osnovu različitih kriterija koji se kose sa načelima ljudskih prava i sloboda što ima za posljedicu osjećaj nesigurnosti,

4. porijeklo na osnovu kojeg se neko dodjeljuje ili određuje nekoj određenoj rasnoj grupi koja predstavlja manjinu u odnosu na ostale stanovnike,

5. vjera - sloboda vjere zagarantovana je međunarodnim dokumentima o ljudskim pravima,

6. pripadnost je jedan od razloga za traženje azila ukoliko se izgubi povjerenje prema grupi kojoj osoba pripada ili prema vladajućem sistemu, sa čime se izlaže progonima i torturama,

7. političko mišljenje - vjerovanje u neka politička mišljenja suprotna politici vladajućeg sistema, što može uzrokovati strah od progona, ali takav strah mora biti opravdan poput istinskog postojanja bojazni da će neko zbog takvih svojih mišljenja biti zatvoren, maltretiran, ponižavan.

\section{Vrste azila}

Postoji nekoliko vrsta azila koje ćemo u nastavku spomenuti i kratko se na njih osvrnuti.

\section{Vjerski azil}

Može se reći da je ovo noviji izraz, jer, unatoč mome skromnom znanju i istraživanju, nisam našao u dostupnoj mi literaturi osvrt na ovaj izraz, definiciju ili objašnjenje njegovog značenja. Međutim, prilikom iščitavanja nekih ajeta i hadisa, moguće je uočiti i definirati ovu vrstu azila.

O ovoj vrsti azila u Kur'anu se govori u slijedećim ajetima:

A kada Ibrabim reče: „Gospodaru moj, učini ovaj grad bębjednim i sačuvaj mene i sinove moje da se klanjamo kumirima, oni su, Gospodaru moj, mnoge ljude na stranputicu naveli. Onaj ko bude mene slijedio - moje je vjere, a onaj ko bude protiv mene ustajao, pa - Ti, uistinu, praštaš i samilostan si. Gospodaru naš, ja sam neke potomke svoje naselio u kotlini u kojoj se nista ne sije, kod Tvoga Casnog hrama, da bi, Gospodaru naš, molitvu obavljali; zato učni da srca nekih ljudi čeznu za njima $i$ opskrbi ih raznim plodovima da bi zabvalni bili. "(Ibrahim, 35-37) 
U njemu su znamenja očevidna - mjesto na kojem je stajao Ibrabim. I onaj ko ude u nj treba da bude bezbjedan. Hodočastiti Hram duð̌an je, Allaba radi, svaki onaj koji je u mogućnosti; a onaj koji neće da vjeruje - pa, zaista, Allah nije ovisan ni o kome. (Ali Imran, 97)

I učinili smo Hram utočistem i sigurnim mjestom ljudima. „Neka vam mjesto na kojem je stajao Ibrabim bude prostor iza koga cete molitvu obavljati!" - I Ibrabimu i Ismailu smo naredili: „Hram Moj očistite qa one koji ga budu obilarili, koju budu tu boravili i koji budu molitvu obavljali."(El-Bekare, 125)

Citirani ajeti jasno ukazuju da je po osnovnom pravilu ove vrste azila dozvoljeno zaštiti svakog onog ko ga zatraži u mekanskom haremu - Kabi. rekao:

U jednom hadisu o ovoj vrsti azila se kaže da je Poslanik, a.s.,

Ibrahim je učinio Mekku svetom $i$ dovio za njene stanovnike, a ja sam Medinu učinio svetom isto kao što je Ibrahim učinio Mekku svetom. ${ }^{14}$

Iz naprijed citiranih ajeta $i$ hadisa moguće je definirati vjerski azil kao svaki bijeg iz mjesta u kojem je nekom ugrožen život i čast u mjesto koje je vjerski sveto i poštovano od strane sljedbenika te vjere.

\section{Lokalno - teritorijalni azil}

To je azil koji se dobije na teritoriji neke remlje koja ga dodjeljuje ${ }^{15}$, ili to je azil kojeg ǔ̌iva azilant na osnovu priznate neporočnosti teritorije na koju je pribjegao arilant. ${ }^{16}$

Ova vrsta azila je poznata kao seoba ili hidžra iz neislamske zemlje u islamsku ili iz nasilničke u pravednu, a objasnio ga je Kur'an u suri EnNisa. Uzvišeni je rekao: Kad budu urimali duše onima koji su se prema sebi ogrijesili, meleci će upitati: „Šta je bilo s vama?" „Bili smo potlačeni na Zemlji", odgovorit će. „Zar Allahova Zemlja nije prostrana $i$ zar se niste mogli nekud iseliti?", reći će meleci, $i$ zato će njihovo prebivaliste biti Džehennem, a uð̌asno je on boraviste." (En-Nisa, 97)

14 Bilježi ga Muslim u svom Sahihu, Knjiga o hadždžu, Poglavlje o odlikovanosti Medine i Poslanikovoj, a.s., dovi, broj hadisa: 1360.

15 Ebul-Veffa, , Ahmedi, El-Kanunud-diplomasi ed-edevli, str. 276.

16 Emrullah, Burhan, Hakkeul-ludžuis-sijasi, dirasetun fi nazirijeti hakekul-luď̌u'i fi kanuniddevlijj, str. 44. 
U Univerzalnoj deklaraciji o ljudskim pravima u 14. članu stoji:

1. svaka osoba ima pravo tražiti azil u drugoj državi i uživati ga kako bi se oslobodila progona,

2. nije dozvoljeno služiti se ovim pravom ako postoji potjera čiji uzrok nije političko neslaganje, a niti su djela koja su oprečna intencijama i načelima Ujedinjenih nacija.

Dakle, ratne žrtve i izbjeglice koje traže utočište i azil su kategorije na koje se odnosi ova vrsta azila. Oni predstavljaju najveći broj azilanata, s tim što se kod azilanta uvjetuje da prije nije počinio neki kriminal, ili ako ga je počinio - da u tom slučaju između dvije države postoji sporazum o izručenju zločinaca. Ovdje, također, treba istaći da je ova vrsta azila jedina vrsta koju država koja je udomila azilante derivira kao privilegiju koju uživa na osnovu svoga suvereniteta. ${ }^{17}$

\section{Diplomatski ili politički azil}

Misli se na azil kojeg azilant traži od neke strane države, ili njene ambasade, ili od nekih njenih brodova, ili aviona da ga zaštite na kraći ili duži period od opasnost koje ugrožavaju njegov život i zdravlje zbog njegovih političkih stavova koji su suprotni zvaničnoj politici njegove države.

Dodjelom političkog azila država koja je primila azilanta dobiva dvije veoma bitne obaveze:

1. Poštivanje azilanata od strane države koja im dodijelila azil, što podrazumijeva pružanje neophodne pomoći, kao i upotreba zakonskih odredbi protiv onih azilanata za koje se smatra da predstavljaju opasnost za nacionalnu sigurnost i državni poredak, i to nakon što budu upozoreni i ukaže im se na njihovo kršenje obaveza kojih su se bili dužni pridržavati kao politički azilanti. Potom ih ima pravo protjerati.

2. Kada neka država dodijeli nekom politički azil, dužna ga je čuvati i štiti od bilo kakvih pokušaja njegova uznemiravanja ili likvidiranja od strane njegove matične zemlje. ${ }^{18}$

\footnotetext{
17 Vidi: www.un.org, www1.umn.edu, www.nchr.org

18 Vidi: Dairetuš-šsunil-lad:̌ri in, www.plod.org
} 


\section{Prava azilanata u islamskom i međunarodnom pravu}

\section{Prava azilanata $u$ islamskom pravu}

I pored toga što su mnoge države prije pojave islama priznale azilantima njihova prava, ipak su ih nakon toga prihvatale kao građane drugog reda i nisu im priznavale pravne sposobnosti koliko su to bile dužne. Nakon što se islam pojavio, prava izbjeglica i azilanata su dobila odgovarajuće poštovanje. Islam im je priznao prava na osnovu kojih su mogli dobiti mjesto koje odgovara njihovoj situaciji. Na taj način su im bila zaštićena osnovna ljudska prava poput prava na život, vjeru, imovinu, čast i razum.

Budući da se islam, putem svojih normi i propisa, brine o pravima i slobodama ljudi (uključujući i izbjeglice i azilante), u nastavku ove studije će biti riječ o nekim pravima koje je islam zagarantovao kategoriji azilanata/izbjeglica. Riječ je o slijedećim pravima:

\section{Pravo azilanta da uđe u islamsku državu i boravi na njenoj teritoriji sukladno svojim potrebama i interesima}

Ukoliko azilant odluči zatražiti azil u islamskoj državi radi zaštite svog života, zdravlja i sigurnosti, vladaru ili njegovom zamjeniku, tj. nadležnim vlastima, se preporučuje ili, možda je preciznije reći da im je to vjerska dužnost, da ga zaštite ako je došao radi spomenutog, jer islam zagovara slobodu i pravdu za sve ljude i osuđuje nasilje i nepravdu bez obzira od koga dolazi i nad kim se provodi. To potvrđuje i slijedeći ajet: „Ako te neki od mnogobožaca zamoli za zaštitu, ti ga zaštiti da bi saslušao Allahove riječi, a potom ga otpremi na mjesto pouzdano za njega. To zato sto oni pripadaju narodu koji ne zna". (Et-Tevbe, 6)

Dakle, ularak u islamsku zemlju radi spomenute potrebe je jedno od prava koje je izbjeglicama i arilantima dalo islamsko rakonodavstvo, pod uvjetom da u tome nema stete, a niti prestanka razloga za davanje azila. ${ }^{19}$

19 Ševkani, Muhammed b. Ali b. Muhammed, Fethul-Kadir, 2/338. 


\section{Pravo azilanta na zaštitu svoje vjere, tj. na njeno upražnjavanje i konzumiranje}

Niko nema pravo prisiliti azilanta da promijeni svoju vjeru i prihvati islam. To se jasno vidi iz slijedećeg ajeta: $U$ vjeru nije dozvoljeno silom nagoniti - pravi put se jasno rąlikuje od zablude! Onaj ko ne vjernje u

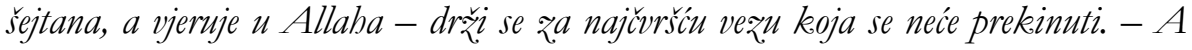
Allah sve cuje $i$ zna. (El-Bekare, 256)

Tumačeći ovaj ajet imam Kurtubi je rekao: „Ajet eksplicitno ukazuje da se niko ne smije prisiliti na primanje islama. ${ }^{120}$

Islam poštuje i zagovara vjerske slobode. Ukoliko obratimo pažnju na historiju islama, pronaći ćemo brojne dokaze za to. Ibn Ishak bilje ži da je ned ̌ransko ižaslanstvo (kršcani), kada je došlo Poslaniku, a.s., u Medinu, ušlo kod njega u njegovu ď̃amiju poslije ikindije. Počli su obavljati svoju molitvu. Neki od ashaba su ib htjeli spriječili, ali je Allabov Poslanik, s.a.v.s., rekao: „Ostavite ib!" Nakon tib riječi oni su se okerenuli istoku i obavili svoju molitvu.

\section{Pravo azilanta na život}

Ovo pravo je opće pravo svih ljudi, pa tako i azilanata. U slučaju da neko od muslimana namjerno ubije azilanta islamske države, nad njim će se izvršiti smrtna kazna (odmazda) isto kao i da je ubio muslimana. Od Abdullaha b. Amra se prenosi da je Poslanik, a.s., rekao: „Ko ubije nemuslimana šticenika née osjetiti džennetskog mirisa koji se osjeti na daljini od cetrdeset godina. ${ }^{22}$ Isto tako se prenosi da je Alija, r.a., ubio jednog muslimana, nakon što je dokazano da je bespravno ubio nemuslimana štićenika. On je rekao: „Ko ima našu zaštitu, njegova krv je kao i naša. ${ }^{23}$ Dakle, iz navedenih primjera se vidi da je azilant koji dođe na teritoriju islamske države pod njenom zaštitom i brigom, pa makar bio i nemusliman.

\footnotetext{
20 Kurtubi, Ebu Abdullah, El-Dřami’u li abkamil-Kur'ani, 3/276.

21 Ibnul-Kajjim, Zadul-me'ad, 3/39.

22 Bilježi ga Buharija u svom Sahihu, Knjiga o glavarini, Poglavlje o bespravnom ubistvu štićenika, broj hadisa: 2995.

${ }^{23}$ Ibn Abidin, Reddul-mubtar alad-Durril-mubtar, 3/273.
} 


\section{Pravo azilanta na zaštitu razuma - mišljenja}

Razum je preduvjet šerijatske odgovornosti i radi njega je Uzvišeni odlikovao čovjeka nad ostalim stvorenjima. Uzvišeni kaže: Allah vam tako objašnjava propise svoje da biste rąmislili. (El-Bekare, 242) Mi vam ižnosimo dokaze, ako pameti imate. (Ali Imran, 118)

Iz priloženog je posve jasno da islam daje veliku važnost razumu i obavezuje da se on čuva i štiti. Bilo kakvo ugrožavanje istog je strogo zabranjeno, bez obzira na vjersko ili ideološko ubjeđenje njegovog vlasnika. ${ }^{24}$

\section{Pravo azilanta na zaštitu časti}

Zaštita časti je staro načelo koje je priznato i u islamu i u predislamskom dobu. Dodjela azila od strane muslimana podrazumijeva $i$ zaštitu njegove časti. Dakle, nije dozvoljeno ugrožavati je na bilo koji način (klevetom, potvaranjem, ogovaranjem itd.) i od strane bilo koga. Ibn Hazm veli: Kada črjek okleveta čovjeka, makar bio i nemusliman, dǔ̌nost je nad njim iquršiti hadd - šrijatsku fiksnu kąnu, jer je Uzvišeni u Kur'anu za sljedbenike Knjige rekao da su čestiti. ${ }^{25}$ (...) i čestite vjernice su vam dozvoljene, i cestite kéeri onih kojima je data Knjiga prije vas... (El-Maide, 5)

U djelu Ed-Durrul-mubtar stoji: Dužnost je otkloniti nengodnosti od njih $i$ zabraniti da se ogovaraju isto kao $i$ da su muslimani. ${ }^{26}$

\section{Pravo azilanta na pristojan stan}

Azilant ima pravo izabrati prikladan stan gdje će boraviti. Dozvoljeno mu je da kupi sve što mu je potrebno za vrijeme njegova azila (prijevozno sredstvo, odjeća, hrana itd.). Isto tako, njegov stan je svet $i$ neprikosnoven i stoga nikome nije dozvoljeno, bez njegove dozvole, wíi u njega, a niti ga je bez. opravdanog šerijatskog razloga dozvoljeno uznemiravati $i$ ugnjetavati $u$ nјети.

\footnotetext{
${ }^{24}$ Ibn Abidin, Reddul-mubtar alad-Durril-mubtar, 3/287.

25 Bagdadi, Muhammed b. Habib, El-Mibber, str. 352.

${ }^{26}$ Ibn Abididn, Redul-mubtar aled-D urrul-mubtar, 3/273.

27 Zejdan, Abdulkerim, Abkamuz-zimmijjine vel-must'eminin fi daril-islam, str. 125.
} 


\section{Pravo azilanta na privatan život i privatnu svojinu}

\section{a) Pravo na privatan život}

Azilant ima pravo da surađuje s ljudima, ima pravo da kupuje sve što mu je potrebno za vrijeme svog azila (prijevozno sredstvo, odjeća, hrana). Potvrđeno je i preneseno od Poslanika, s.a.v.s., da je surađivao sa nemuslimanima. Od Abdurrahmana b. Bekr, r.a., se prenosi da je rekao: „Bili smo s Poslanikom, s.a.v.s., kada mu je došao neki idolopoklonik, rašcupane kose i visok, tjerao je sa sobom svoje ovce. Poslanik, a.s., mu je rekao da mu it proda, pokloni ili da na dar. Covjek je rekao: „Ne, ništa od toga ne dolazi u obzir osim prodaje", pa ih je Poslanik, a.s., i kupio. ${ }^{\text {r2 }}$ Ove citirane riječi (pa ib je kupio) su dokaz da je dozvoljeno vršiti transakcije sa nevjernicima i nemuslimanima.

Dakle, ukoliko neko od azilanata u islamskoj državi bude nemusliman ili nevjernik, dozvoljeno mu je da trguje, kupuje i prodaje, ali u granicama onoga što dozvoljava Šerijat, jer isto tako je i muslimanu dozvoljeno trgovati sa nemuslimanima samo u granicama dozvoljenog po islamskom zakonodavstvu.

\section{b) Pravo na privatnu imovinu}

Azilant ima pravo posjedovati sve ono što mu je potrebno za normalan život i pored toga što se smatra strancem u islamskoj državi. Ibn Tejmijje ističe da je država, nakon što je azilantu dala pravo na azil, dala i pravo na posjedovanje i privatnu imovinu.

\section{Pravo azilanta na ličnu slobodu}

Prema islamskom učenju, Allah je stvorio sve ljude slobodne od bilo kakve krivice, obaveze ili grijeha. Stoga je Omer, r.a., imao pravo kada je rekao Ibnul-'Asu: „Od kada ste ljude učinili robovima, a njihove majke su ih rodile slobodnim!? ${ }^{29}$ Ova vrsta lične slobode zagarantovana je azilantu radi realizacije društvene sigurnost i mira, ističe Muhammedi es-Sadik Afifi.

\footnotetext{
${ }_{28}$ Bilježi ga Buharija u svom Sahihu u Knjizi o kupoprodaji, Poglavlje o kupoprodaji od idolopoklonika i ratnika, broj hadis: 2103.

${ }^{29}$ Afifi, Muhammedi es-Sadik, El-Mudžteme'ul-islami vel-alakatud-devlijje, str. 67.
} 
Svi ljudi su po svojoj ljudskoj prirodi jednaki. Uzvišeni je rekao: $M i$ smo sinove Ademove, doista, odlikovali; dali smo im da kopnom $i$ morem putuju, $i$ opskrbili ib ukusnim jelima, $i$ dali im velike prednosti nad mnogima koje smo stvorili. (El-Isra, 70)

Dakle, Uzvišeni Allah je dao prednost covjeku nad ostalim stvorenjima, a to potvrduje identicnost njïhove prirode iz cega proistič obaveza zaštite i očuvanja ljudske lične slobode, osim u onim stvarima koje je islam postavio kao načela $i$ principe po kojima ce se ljudi razlikoovati $i$ odlikovati, tj. koje su ograničene serijatskim propisima. ${ }^{30}$

\section{Pravo azilanta da naslijedi i da bude naslijeđen}

Međutim, musliman može naslijediti nemuslimana $i$ ovo mišljenje zastupa vecina pravnika ashaba. ${ }^{31}$

\section{Pravo azilanta da ne bude vraćen u zemlju iz koje je protjeran}

Ovo je možda najvažnije pravo kojem teži azilant, jer ono ga štiti da ne padne u ruke nasilničkom režimu države koja ga je protjerala. S obzirom na važnost ovog prava, islamsko zakonodavstvo ga je priznalo $\mathrm{i}$ zaštitilo. Ebu Talib je odbio da preda Allahovog Poslanika, a.s., Kurejševićima, rekavši, nakon što je kategorički odbio njihov zahtjev o njegovu izručenju, slijedeće: ..Nastavi svoju misiju i radi šta ̌̌eliš, a ja te, tako mi Allaha, né́u nikada iaruciti. ${ }^{\text {‘2 }}$

\section{Pravo azilanta na obrazovanje i edukaciju}

Islam je zagarantovao svakom azilantu pravo na obrazovanje. U djelu Kenzul-'ummal stoji: Poslanik, a.s., je naredio da svaki musliman kod sebe urme po jednog covjeka iz. izaslanstva Abdul-Kajsa, da ga opismeni i nauci namazu. ${ }^{33}$

Dakle, Poslanik, a.s., je ljude koji su zatražili zaštitu kod njega, od nevjernika Medra, lijepo primio, ugostio i naredio da se opismene.

\footnotetext{
${ }^{30}$ Ebu Zehre, Muhammed, El-Alakatud-devlijetu fil-islam, str. 37.

${ }^{31} \mathrm{Ibn}$ Rušd, Bidajetul-mudžtehid ve nihajetul-muktesid, 2/454.

${ }^{32}$ Ibn Kesir, El-Bidaje ven-nihaje, 3/93.

${ }^{33}$ Hindi, Alauddin Ali b. Husamuddin el-Mutteki, Kenzul-ummal, 3/113.
} 
Postoji još mnogo drugih prava koja je islam priznao azilantima. Sva se ta prava uglavnom svode na zaštitu njihovih života i lijepo ophođenje prema njima

$\mathrm{Na}$ kraju ovog poglavlja s pravom možemo zaključiti da islam daje azilantima ista prava kao i svojim građanima, jer je osnovno načelo islamske filozofije da su svi ljudi stvoreni od jednog čovjeka i jedne žene. Dakle, ravnopravni su, i niko nema prava da jedne izdigne nad drugima zbog nekih činjenica na koje oni nisu mogli direktno ili indirektno utjecati. Čovjek je najodabranije Božije stvorenje i taj njegov položaj mora biti zaštićen. Stoga je progon i poniženje svakog čovjeka, po bilo kojoj osnovi, suprotno islamu, a pružiti utočište prognanim i poniženim obaveza i dio islama.

\section{Prava azilanata u međunarodnom pravu}

Pod ovim podnaslovom ćemo se ukratko osvrnuti na najvažnija prava azilanata $\mathrm{u}$ međunarodnom pravu koja su navedena $\mathrm{u}$ međunarodnim dokumentima i deklaracijama o ljudskim pravima.

\section{Pravo azilanta da ne bude vraćen u zemlju iz koje je protjeran}

Ovo je esencijalno pravo u zakonima o azilu. S obzirom na njegovu važnost, međunarodni dokumenti o ljudskim pravima i pravima izbjeglica su mu posvetili posebnu pažnju. U Univerzalnoj deklaraciji Ujedinjenih naroda, prva stavka, trećeg člana, kaže: „Nije dozvoljeno da bilo koji azilant bude izložen posebnim procedurama, poput zabrane ulaska u neku državu na njenim granicama, ili da, nakon što uđe na teritoriju neke zemlje u koju se skloni, bude udaljen ili da silom bude vraćen u bilo koju državu u kojoj će biti izložen torturi. “ 34

\section{Ograničenje prava države na izručenje azilanata}

Ovo načelo se smatra primjenom prethodnog prava po kojem nije dozvoljeno silom vratiti azilanta državi koja ga teroriše.

Ovo načelo je navedeno u Konvenciji o statusu izbjeglica iz 1951. god. koja se odnosi na status zakona o azilantima, kao i u dodatnom protokolu iz 1967. god. Burhan Emrullah u El-Lud乏̌u'us-sijasi, dirasetun fi

\footnotetext{
34 Abdul-'Ali, Muhammed Ševki, Hukukul-laď̌i'ine tibkan li mevasikil-umemil-muttehide, str. 40.
} 
nazarijeti hakekil-melď̌e'i fil-kanunid-devlijj ističe da te konvencije involviraju tri garancije zaštite prethodnog prava, a to su:

a) ograničava se vlast države po pitanju udaljavanja azilanta i to kao zabrana protjerivanja,

b) obaveznost primjene određene procedure pri izdavanju odluke o izručenju, pri čemu se nalaže da se poštuju pravila i metode koje propisuje zakon koji nalaže da se treba dati pravo azilantu da dokaže svoju nevinost, pravo na opovrgavanje odluke i pravno zastupništvo,

c) azilant treba imati dovoljno vremena kod izdavanja odluke o konačnom izručenju kako bi imao mogao pronaći novo prebivalište.

\section{Prava azilanta na jednakost i zabrana rasizma}

Kada je na međunarodnom nivou počelo interesovanje za ljudska prava, načelo jednakosti među ljudima je bilo jedno od najvažnijih principa na kojim su i zasnivani međunarodni dokumenti o ljudskim pravima. Također, zauzima važno mjesto i u Konvenciji o statusu izbjeglica iz 1951. godine gdje se u 3. članu navodi: „Dræ̌ave potpisnice ove konvencije su duð̆ne na azilante primijeniti ovo načelo ne praveći među njima raqliku

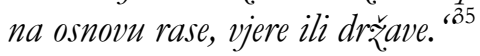

Dakle, može se zaključiti da je kršenje principa jednakosti jedan od osnovnih razloga za traženje azila, zbog čega azilanti bivaju prisiljeni potražiti utočište u stranim državama.

\section{Pravo azilanta na slobodu kretanja}

Pod ovim pravom se misli na mogućnost osobe da slobodno i dobrovoljno promijeni mjesto svog boravka. Neki ovo pravo nazivaju i pravo na kretanje.

Moguće je napraviti razliku između različitih vrsta kretanja (kopnenim, vazdušnim i vodenim putem). Ipak, najčešće se putuje kopnom. U 26. članu iz Konvencije o statusu izbjeglica iz 1954. god. navodi se: „Svaka remlja potpisnica Konvencije je rakonski duřna dozvoliti

35 Šerkavi, Su'ad, Nisbijjetul-burijatil-'ammeti ve in'ikasatiba 'alettenzimid-devlijj, str. 85. 
azilantima koji borave na njenoj teritoriji pravo izbora mjesta njïbova boravka kao $i$ slobodno keretanje na svojoj teritoriji. 36

\section{Pravo azilanta na povratak}

U Univerzalnoj deklaraciji o ljudskim pravima se potvrđuje pravo i na povratak. U 13. članu se kaže: „Svaka osoba ima pravo napustiti svaku zemlju pa $i$ svoju. Isto tako ima i pravo da se vrati u svoju dr:̌avu. ${ }^{\text {‘37 }}$

U Univerzalnoj deklaraciji se ističe da je pravo svih izbjeglica i azilanata da se vrate u svoje zemlje koje su napustili zbog progona i da je to pravo zagarantovano svim izbjeglicama.

Prema tome, načelo prava na povratak ima svoju zakonsku osnovu koja je zagarantovana u svim izvorima Medunarodnog zakona o ljudskim pravima $i$ da tu osnovu podř̌avaju $i$ sną̧e svi izvori medunarodnog prava, iz čega proistice set zakonskih obaveza cije propise i norme su duð̌ni postovati oni kojima su one $i$ upućene. ${ }^{38}$

\section{Pravo azilanta na kompenzaciju}

Misli se na kompenzaciju onoga što su izbjeglice izgubile zbog prekida rada i nemogućnosti da zaštite svoju imovinu, što je rezultat njihovog iseljenja iz matične zemlje. Pod ovim pravom se još podrazumijeva i nadoknada za duševne bolove koje su izbjeglice pretrpjele zbog progonstva.

Pravo na nadoknadu se prvi put spominje u odluci Generalne skupštine Ujedinjenih nacija. U 11. članu se kaže da se mora platiti za izgubljenu imovinu, kao i za svaku štetu ili devalvaciju koja je nastala na toj imovini sukladno zakonskim načelima i odredbama.

\section{Pravo azilanata na obrazovanje}

U 22. članu Konvencije o statusu izbjeglica iz 1951. godine stoji: „Dř̌ave ugovornice cé u pogledu osnovne nastave primjenjivati prema izbjeglicama isti

\footnotetext{
36 Vidi: Posebna konvencija o statusu azilanata za 1951. god., (www.unhcr.org.eg)

37 Vidi: UN, Ljudska prava u Međunarodnoj deklaraciji o ljudskim pravima (www.un.org)

${ }^{38}$ Džundi, Ibrahim, El-Ladži'unel-felstinijin bejnel-'avde vet-tevtin, str. 22.
} 
postupak kao i prema svojim drǎavljanima. ${ }^{\text {(B9 }}$ Bitno je istaći da je pravo na obrazovanje jedno od osnovnih prava po kojem su svi ljudi izjednačeni, pa tako i izbjeglice. 26. član Opće deklaracije o ljudskim pravima izričito ističe pravo svakog čovjeka na obrazovanje: „Svatko ima pravo na odgoj $i$ obrazovanje. Odgoj $i$ obrazovanje mora biti besplatno, barem na osnounom $i$ općeobrazovnom stupnju. ${ }^{*} 0$

\section{Pravo azilanta na zdravstvenu zaštitu}

Svjetska zdravstvena organizacija je pojam primarne zdravstvene zaštite definisala kao osnovnu zdravstvenu zaštitu koja je učinjena pristupačnom po cijeni koju zemlja i društvo mogu priuštiti, uz metode koje su praktične, znanstveno i socijalno prihvaćene, uz obavezu na pravičnost u distribuciji sredstava za zdravlje i zdravstvenu zaštitu te univerzalnu pokrivenost populacije sa osnovnim preventivnim i kurativnim uslugama koje promoviraju zdravlje ili kontroliraju bolest koja se pruža svakom građaninu u nekoj zemlji. ${ }^{41}$

Prema tome, kada izbjeglice zatraže zaštitu u nekoj zemlji, obaveza te zemlje je da im omogući minimalnu zdravstvenu zaštitu zbog svega onoga čemu su bili izloženi tokom njihova progona (manjak hrane, fizički napor, strah, stres itd.).

Države potpisnice Konvencije o statusu izbjeglica su obavezne da ih zaštite.

\section{Pravo azilanta na državljanstvo}

Neki pravnici državljanstvo definiraju kao pripadnost jedne osobe određenom narodu. ${ }^{42}$ Prema toj definiciji, državljanstvo se temelji na postojanju društvene veze kroz tradiciju, običaje i želju za zajedničkim življenjem.

Sa pravne strane, državljanstvo je svojstvo kod neke osobe koje implicira postojanje zakonske veze između nje i određene države. ${ }^{43}$

39 Vidi: Konvencija o statusu izbjeglica iz 1951. god., (www.unhcr.rs)

40 Opía deklaracija o ljudskim pravima iz 1948., član: 26., str. 7.

41 Vidi: Međunarodna zdravstvena organizacija (www.who.int)

${ }^{42}$ Džebr, Muhammed, El-Merkezud-devli lil-ekallijat fil-kanunid-devlijjil-'am, str. 269.

43 Ibid. 
Pošto je državljanstvo svojstvo koje je u tijesnoj vezi sa onim koji ga nosi, onda je nužno da ono odražava njegovu pripadnost nekoj određenoj državi, te se ta pripadnost jača i snaži. Države koje su primile izbjeglice $\mathrm{i}$ azilante u potpunosti treba da shvate spomenuta značenja $\mathrm{i}$ osjećaje. Obaveza tih država je da im omogući uživanje državljanstva države u kojoj borave. ${ }^{44}$

U međunarodnom pravu postoje još i druga prava izbjeglica i azilanata koja se većinom odnose na opća prava i slobode poput prava na hranu, odjeću, rad itd.

\section{Prestanak azila u islamskom i međunarodnom pravu}

\section{Prestanak azila u islamskom pravu}

Najčešći uzroci zbog kojih azilantu prestaje status azila u islamskom pravu su:

a) smrt - Smrt je prirodan u₹rok putem kojeg prestaje status azila jer je njegov kontinuitet poslije smrti umrlog nemoguć. ${ }^{45}$

b) prestanak terora i nasilja - Jednim studioznim proućavanjem događaja koji su se desili u povijesti islama i koji su zabilježeni u djelima o Poslanikovom životopisu - siri, moguće je usturditi da islamsko pravo sadrǎava set praktičnih primjera koji ukazuju da se azil završava sa prestankom uzroka straba $i$ torture. Tako npr. mnogi muslimani koji su izbjegli u Abesiniju su se vratili u Mekeku kada su Omer i Hamza, r.a., primili islam, jer je do njih doprla vijest da su muslimani postali sigurni od kurejševičkih uqnemiravanja i provokacija. ${ }^{46}$

c) ismijavanje sa vjerom i muslimanima - Ako azilant pokaře nešto što ukazuje na ponižavanje $i$ ismijavanje islama, njegova učenja, muslimana $i$ njihovih velikana itd., njegov azil ce se smatrati završenim jer mu muslimani azil nisu dali da se ismijava s njima i ponižava njïhovu vjeru. ${ }^{47}$

4. izdaja - pod tim se misli da azilant radi direktno ili indirektno protiv države koja mu je dala azil, ili da je izda. Ta izdaja može biti urađena na različite načine (šurovanje s neprijateljem, učestvovanje u

\footnotetext{
44 Vidi: Posebna konvencija o statusu azilanata za 1951. god., (www.unhcr.org.eg)

45 Ebul-Vefa, Ahmed, El-'Ilamu bi kava'idil-kanunid-devlijji vel-'alaktud-devlijje fiš-šeri'atilislamijje, 6/469.

${ }^{46} \mathrm{Ibn}$ Kesir, El-Bidajetu ven-nihaje, 3/114.

${ }^{47}$ Muhammed, Abdullah, El-Ludžu'u fil-islam, str. 7.
} 
raznim krijumčarenjima, špijunaža u korist neprijatelja itd.). U slučaju da azilant počini nešto od spomenutih ili sličnih stvari, islamska država ima pravo uskratiti mu azil. To dokazuje slijedeći tekst: „Cim primijetiš vjerolomstvo nekog plemena, i ti njemu isto tako otkaži ugovor - Allah uistinu ne voli vjerolomnike". (El-Enfal, 58) Osvrćući se na značenje ovog ajeta, imam Kurtubi kaže: „Kada se pojave tragovi izdaje i objelodane se njeni dokazi, dužnost je prekinuti ugovor kako ne bi odugovlačenje u tome dovelo do propasti. "A8

\section{Prestanak azila u međunarodnom pravu}

Najvažniji razlozi zbog kojih prestaje status azila u međunarodnom pravu su:

1. smrt,

2. ekstradicija - država koja daje azil ima pravo i da ga ograniči ekstradicijom ili protjerivanjem azilanta. Posebna deklaracija o azilantima i izbjeglicama je dozvolila protjerivanje azilanta, ali sukladno slijedećim pravilima:

a) država koja primi azilanta ili izbjeglicu nema pravo da ga protjera osim zbog nacionalne sigurnosti ili javnog reda,

b) dř̌ava koja primi ąilanta ili izjeglicu nema pravo da ga protjera sve dok isti ne dobije dozvolu za ulazak na teritoriju druge države ${ }^{49}$,

3. dobrovoljni povratak - kada se azilanti ili izbjeglice dobrovoljno vrate u svoju zemlju, to je najidealniji način za okončanje azila,

4. primanje državljanstva države koja je dodijelila azil - ukoliko država koja je ugostila azilanta njemu dodijeli dræ̌avljanstvo - azil se okončava, jer azilant tada počinje uřivati državljanstvo te države, a ne svoje matične. ${ }^{50}$

\section{Zaključna razmatranja}

Ova studija je polučila slijedeće rezultate:

\footnotetext{
48 Kurtubi, Ebu Abdullah, El-Dą̌mi'u li abkamil-Kur'an, 8/33.

${ }^{49}$ El-Gunejmi, Hamdi, El-Meldže'u fil-kanunid-devlijj, str. 639.

50 Ebul-Vefa, Ahmed, El-'Ilamu bi kava'idil-kanunid-devlijji vel-'alakatud-deviijje fiš-seri'atilislamijje, 6/469.
} 
- azil u islamskom pravu je plemenitiji nego u međunarodnom pravu s obzirom na njegov izvor; Allah je izvor svih prava u islamu, pa i azila i On je plemenitiji i uzvišeniji od svakog drugog,

- islamsko pravo dodjeljuje azil svakoj osobi bez obzira na rasu, vjeru i naciju, čak i neprijatelju islamske države, ukoliko uđe na njenu teritoriju na osnovu ugovora o zaštiti, tj. emana -vize,

- u islamskom pravu, azilant uživa sva navedena prava na svakom mjestu i regiji, tj. na teritoriji svih njenih država i pokrajina s obzirom na njegov identičan izvor iz kojeg se crpe njegovi propisi i norme, za razliku od azila u međunarodnom pravu čije konzumiranje se ograničava samo na državu koja ga izda i ne važi na teritoriji drugih država,

- odnos prema azilantu u islamskom pravu zasniva se na islamskom načelu koje se fokusira na ljudsku dimenziju, tj. na čistu ljudsku prirodu, koja po svojoj suštini i strukturi naginje istini i pravdi,

- azil se smatra jednom vrstom ugovora koji pretpostavlja postojanje dviju strana i zbog toga se on ne može zaključiti, ako se ne ispune uvjeti zaključenja ugovora, te se može i poništiti ukoliko azilant ne ispuni svoje obaveze prema državi, tj. onome koji je dodijelio azil,

- azil je ljudska potreba koja zahtijeva miješanje država radi pomoći azilantu,

- islamsko pravo zagovara nužno pronalaženje i obezbjeđenje sigurnosti za azilanta nakon završetka azila i ovo je jedinstven propis islamskog prava kojeg međunarodna prava ne poznaju,

- načela i principi zaštite azilanata, kao i zaštita ljudskih prava, u islamu su nastala davno, prije četrnaest stoljeća, ali je dokazano da su primjenljiva u svakom vremenu i prostoru, te da su utoliko inovacijske prirode koliko se inoviraju društvene zajednice i države,

- povratak azilanta u državu iz koje je izbjegao je sveto pravo, kako u islamskom, tako i u međunarodnom pravu, stoga ga nema niko pravo poništiti, odreći ga se, niti se s njim poigravati,

- pravo azilanta na kompenzaciju je zagarantovano, kako u Šerijatu, tako i u međunarodnom pravu; to je nadoknada azilantu zbog prekida posla, za sve uništeno zbog progona i za duševnu bol zbog trauma koje je doživio. 


\section{Popis literature:}

1. Abdul-'Al, Muhammed Ševki, Hukukul-laď̌i'i tibkan li mevasikil-umemil-mettehide 2. Ibn Abidin, Muhammed Emin b. Omer b. Abdulaziz ed-Dimiški, Hašijetu Ibn Abidin, 1900.

2. Afifi, Muhammedi es-Sadik, El-Mudžteme'ul-islamïj vel-alakatud-devlijje, Muessesetulhandži

3. Askalani, Šihabuddin ebul-Fadl Ahmed b. Ali b. Muhammed b. Muhammed ibn Hadžer el-Kenani, Fethul-Bari šrh Sahibil-Buhari, Kairo, Misr, Daru Ebi-Hajajn, 1996.

4. Bagdadi, Muhammed b. Habib Umejje b. Omer el-Hašimi, El-Mibber, Bejrut, Liban, Darul-afakil-džedide, 1900.

5. Buhari, Ebu-Abdullah Muhammed b. Ismail b. Ibrahim el-Mugire, Sabihul-Buhari, Bejrut, Liban, Darul-fikr, 1994.

6. Ganim, Muhammed Hafiz, Mebadi'ul-kanunid-devlijjil-am, dirasetu bi davabitibil-usulijje ve li abkamihil-amme, drugo izdanje, Kairo, Egipt, Štamparija egipatska, 1959.

7. Ebu Hejf, Ali Sadik, El-Kanunud-devlijjil-'am: en-nezarijatu vel-mebadi'ul-'amme, ešhasulkanunid-devliji, Aleksandrija, Egipat, 1900.

8. Ebul-Vefa, Ahmed, El-Kanunud-diplumasijjid-devlijj, Darun-nehdatul-arabijje, Kairo, 1992.

9. Emrullah, Burhan, Hakkul-ludžuis-sijasijj, dirasetu fi nezarijeti-hakekil- meldže'i filkanunid-devlijji, Darun-nehdatul-arabijje, Kairo, 1982.

10. Ebtah, Al-Laď̌íine fil-mefbumil-islami, muessesetud-dirastail-felestinijje,, Bejrut, prvo izdanje, 1996.

11. Ibn Kesir, Imaduddin Ebul-Fida Ismail b. Kesir el-Kureši ed-Dimiški, TefsirulKur'anil-ątim, Daru ihjail-kutubil-arabiji, 1994.

12. Kurtubi, Ebu Abdullah Muhammed b. Ahmed el-Ensari, El-Džami'u li abkamilKur'an, treće izdanje, 1996., Darul-hadis, El-Kahire.

13. Maverdi, Ebul-Hasan ali b. Muhammed b. Habib, En-Nuketu vel-'ujun, Bejrut, Liban, Darul-kutubil-'ilmijje, 1992.

14. Sujuti, Dželaluddin Abdurrahman b. Ebi Bekr b. Muhammed b. Sabikuddin elHudajri, Lubabun-nukuli fi esbabin-nuzuli, et-tab'atus-salise, Bjerut, Lubnanm Daru ihjai-ulumi, 1980.

15. Šekani, Muhammed b. Ali b. Muhammed b. Abdullah, Fethul-Kadir: El-Džemi'ussagir bejne fennejir-rivajeti ved-dirajeti min 'ilmit-tefsir, treće izdanje, El-Mensure, Misr, Darul-Vefa, 2005.

16. Ibn Kesir, Imaduddin Ebul-Fida Ismail b. Kesir el-Kureši ed-Dimiški, TefsirulKur'anil-azim, Daru ihjail- kutubil-arabijj, 1994. 
17. Muslim, Ebul-Husejn Muslim el-Kušejri en-Nejsaburi, Sabihu Muslim, Bejrut, Liban, Darul-kutubul-ilmijje, 1994.

18. Ebu Zehre, Muhammed b. Ahmed b. Mustafa b. Ahmed b. Abdullah, El'Alakatud-devlijjetu fil-islam, El-Kahire, Misr, Darul-fikril-arebi, 1995.

19. Ibn Rušd, Ebul-Velid Muhammed b. Ahmed b. Muhammed b. Rušd el-Kurtubi elEndalusi, Bidajetul-mudžtehid ve nihajetul-muktesid, Bejrut, Liban, Darul-kutubil-'ilmijje, 2002.

20. Ibn Kesir, Imaduddin Ebul-Fida Ismail b. Kesir el-Kureši ed-Dimiški, El-Bidaje vennihaje, Bejrut, Liban, Mektebetul-me'arif, 1900.

21. Ibn Tejmijje, Ebul-Abbas Tekijuddin Ahmed b. Abdulhalim b. Abdusselam b. Abdullah, Iktidaus-siratil-mustekim muhalefetu ashabil-ď̌ehim, Kairo, Egipat, Darulhadisi, 2003.

22. Hindi, Alauddin Ali el-Mutteki b. Hisamuddin, Ken₹ul-ummali fi sunenil-akvali vel-ef'al, peto izdanje, Bejrut, Liban, muessestur-risale, 1985.

23. Gunejmi, Hamdi, El-Meldžée fil-kanunid-devli, risaletu duktora bi ď̌ami'atil-iskenderijje, kullijjetul-hukuk, 1986.

24. Ibn Menzur, Džemaluddin Eul-Fadl Muhammed b. Mukrim b. Alib. Ahmed, Lisanul-arabi, Bejrut, Liban, Darus-sadir, 1900.

25. Fejruz Abadi, Ebu Tahir Medžduddin Muhammed b. Jakub b. Ibrahim b. Omer eš-Širazi, El-Kamusul-mubit, Bejrut, Liban, Darul-fikr, 1983.

26. Karadavi, Jusuf, Fikhuz-zekati, dirasetun makerenetun li abkamiha ve felsefetiha fi dav'ilKur'ani ves-sunneti, peto izdanje, Bejrut, Liban, Mu'essesetur-risale, 1981.

27. Muftić, Tevfik, Arapsko-bosanski rječnik, treće izdanje, El-Kalem, Sarajevo, 1997.

28. Ebul-Vefa, Ahmed, El-Kanunud-diplumasijid-devlijj, Darun-nehdatul-arabijje, Kairo, 1992.

\section{Internet stranice korištene $\mathrm{u}$ radu:}

29. www.plord.org.

30. www.un.org

31. www.nchr.org

32. www. maktoobblog.com

33. www. unhcr. org. eg

34. www.un.org.

35. www.who.int 


\section{Sulejman Topoljak, PhD}

\section{RIGHTS OF REFUGEES AND ASYLUM SEEKERS IN ISLAM}

\section{ABSTRACT}

The aim of this study is to answer the following questions: do asylum seekers and refugees have any rights according to the teachings of Islam, what are those rights and what is the contemporary situation? Study then makes a comparison between rights of asylum seekers and refugees in Islamic law and international law.

It is obvious that Muslims are today the largest refugees, their numbers increase day by day, and the majority of them are in an unenviable position. This harsh reality implies that the majority of refugees do not enjoy their rights in many countries. This is mostly because of the fact that the states disregard the realization of their obligations upon the refugees, as well as the ignorance of these rights by refugees and asylum seekers. Those rights are guaranteed to refugees and asylum seekers in both Islamic teachings and in international human rights and documents.

In order for the to study yield the expected results, it was necessary to explore the notion of exile in the Qur'an and Sunnah, as well as in the international law, the kind of refuge in the classical period, the causes of displacement in the Islamic and international law, the rights of refugees and the cessation of refugee status in the Islamic and international law.

Keywords: asylum, refugees, Islam, Sharia, refugees, Islamic law, international law, the rights, obligations. 
الأستاذ الدكتور سليمان توبولياك

\section{حقوق المهاجرين واللاجئين في الإسلام}

\section{الخلاصية}

الهدف من هذه الدراسة هو الإجابة على السؤال: هل المهاجرون واللاجؤون لهم

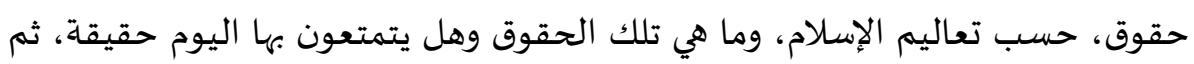
لنقارن بين حقوقهم في الشريعة الإسلامية والقاون الدولي.

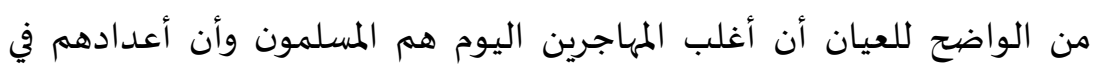

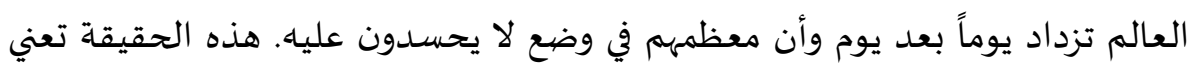

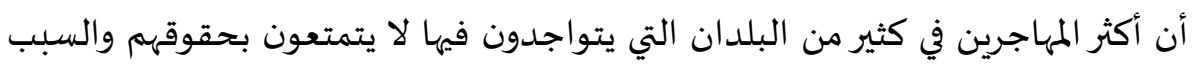

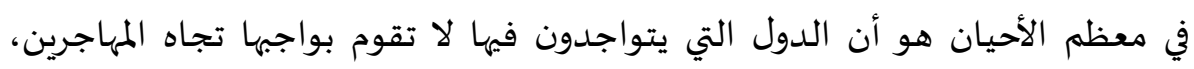

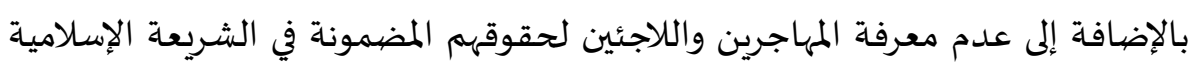
والمواثيق الدولية عن حقوق الإنسان. لكي تعطي الدراسة النتائج المرجوة كان من الضسن الضروري بحث مفهوم الهجرة في

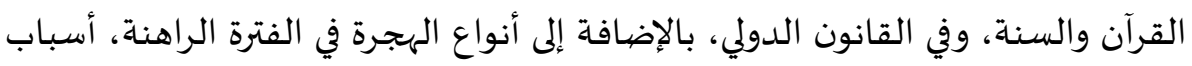

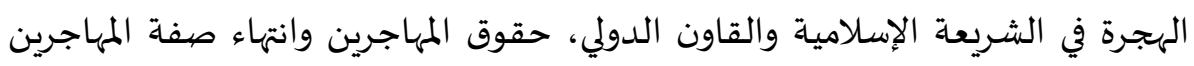
في الشريعة الإسلامية والقاون الدولي.

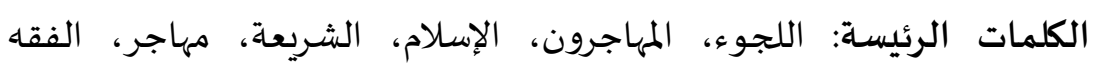
الإسلامي، القانون الدولي، حقوق، واجبات الرئل الموء، المجات 